\title{
EVALUATING EARLY POST-FIRE TROPICAL LOWER MONTANE FOREST RECOVERY IN INDONESIA
}

\author{
Rochimi D, Waring KM* \& Sánchez Meador AJ \\ School of Forestry, Northern Arizona University, Flagstaff, Arizona, 86011 USA \\ *kristen.waring@nau.edu
}

Submitted December 2019; accepted September 2020

\begin{abstract}
Little is known about post-fire tropical montane forest succession in Indonesia. It is an important step to understand whether forests are recovering and if there is a need for reforestation or other rehabilitation efforts. This study assessed the structure and composition of post-fire forest regrowth in Raden Soerjo Grand Forest Park, a conservation forest management unit in East Java, Indonesia. Three high-severity burn units were sampled to assess forest response across a range of post-fire recovery times and one or two fire entries. Mean stems and basal area per unit by size class (tree, pole, sapling and seedling) and tree size class distribution by species, and mean percent cover of understory by life form were calculated. It was found that units experiencing short-term absence of fire and two fire entries were dominated by non-tree understory vegetation, including high grass cover, indicating that understory cover may hamper the establishment of tree regeneration. It was also found that higher species diversity and richness followed a single fire entry. The results provided a better understanding of early post-fire forest recovery. Managers should actively monitor burned areas and plan for active restoration, especially if non-forest vegetation dominates the area for a long period (> 8 years), or after a second fire entry.
\end{abstract}

Keywords: Regeneration, high-severity fire, fire frequency, understory diversity, non-native species

\section{INTRODUCTION}

Indonesia has experienced many large-scale high-severity forest fires in recent years, i.e. 1997, 1998, 2009, 2012 and 2015. In addition to increased loss in forest cover during these fire years, Indonesia has also become one of the highest emitters of greenhouse gasses (GHG) in the world (Fuller et al. 2004, Margono et al. 2014, Hooijer et al. 2010, Pearson et al. 2017, Tepley et al. 2017). High-severity fires are associated with El-Nino Southern Oscillation (ENSO) events which initiate long dry seasons and droughts between May and November (Tacconi et al. 2007, Wooster et al. 2012).

High-severity fire enlarges forest gaps, increasing solar radiation and causing subsequent negative ecological impacts in tropical forests (Tacconi et al. 2007, Jones et al. 2016). Recurring forest fire delays recovery and can alter short- and long-term forest structure and composition (Smiet 1992, Cochrane \& Schulze 1999, Mostacedo et al. 2001, ITTO 2002, Sutomo 2009). In Indonesia, little is known about forest recovery following high- severity fires. Rahmasari (2011) discovered that high severity fire in Raden Soerjo Grand Forest Park (GFP), East Java, reduced species richness, stand density and basal area across all size classes. However, this study only examined a single fire entry (2009), one-year post-fire. Greater understanding of post-fire trajectories is necessary to improve reforestation and rehabilitation efforts, and recover ecosystem services including carbon storage.

To further understand the effect of forest fire in the tropical montane forest, a new research project was established in Raden Soerjo GFP (Figure 1). Raden Soerjo GFP has experienced numerous forest fires, including the recent fires of 2015 (Raden Soerjo GFP Agency 2015). Postfire burn areas were examined to quantify the effects of high-severity fire frequency on post-fire recovery. The research objective was specifically to assess high-severity fire impacts on post-fire forest recovery following different fire frequency (first-entry and second-entry fires), and time since fire (two-, five- and eight-years post-fire). 


\section{MATERIALS AND METHODS}

\section{Study site}

Three study sites were located in Raden Soerjo GFP, East Java, Indonesia, all of which burned at least once since 2009 in high-severity fires (Figure 1). Raden Soerjo GFP is a Conservation Management Unit under the Agency of Forestry, East Java Province, that contains both Mount Arjuno-Welirang and Mount Bromo Tengger Semeru. It is within the Bromo Tengger SemeruArjuno Biosphere Reserve, designated as a World Biosphere Reserve in 2015 by UNESCO. The purpose of a conservation forest is to maintain the biodiversity and all other ecosystem services (Undang-Undang Republik Indonesia, 1990). Geographically, Raden Soerjo GFP is located at $7^{\circ} 40^{\prime}$ latitude and $112^{\circ} 30^{\prime}$ longitude, and is 27,868 hectares in size. Raden Soerjo GFP ranges in elevation from 1,000 to $3,340 \mathrm{~m}$ and is characterised by pronounced cycles of wet and dry seasons. The wet season is typically November-April and is followed by the dry season, May-October. Mean annual precipitation is 2,500-4,500 $\mathrm{mm}$ and mean annual temperature varies between $5-15{ }^{\circ} \mathrm{C}$ (Raden Soerjo GFP Agency 2015).

Tropical montane forest vegetation dominates the Raden Soerjo GFP ecosystem. Typical native tree species composition includes Casuarina junghuniana (cemara gunung), Litocarpus sundaicus (pasang), Engelhardia spicata (kukrup), Pygeum parviflorum (nyampuh), Trema orientalis (anggrung), Pinus merkusii (pinus), Malotus sp. (tutup), Ficus sp. (dampul), Acmena acuminatissima (kelis) and Macropanax dispermum (endos endogan). The understory is composed of herbaceous plants, grasses and shrubs, such as Panicum repens (kolonjono), Chromolaena odorata (grebes), Eupatorium riparium (teh-tehan) and Vaccinium varingiaefolium (manis rejo). Numerous non-native, invasive overstory and understory species are also found in these forest ecosystems.

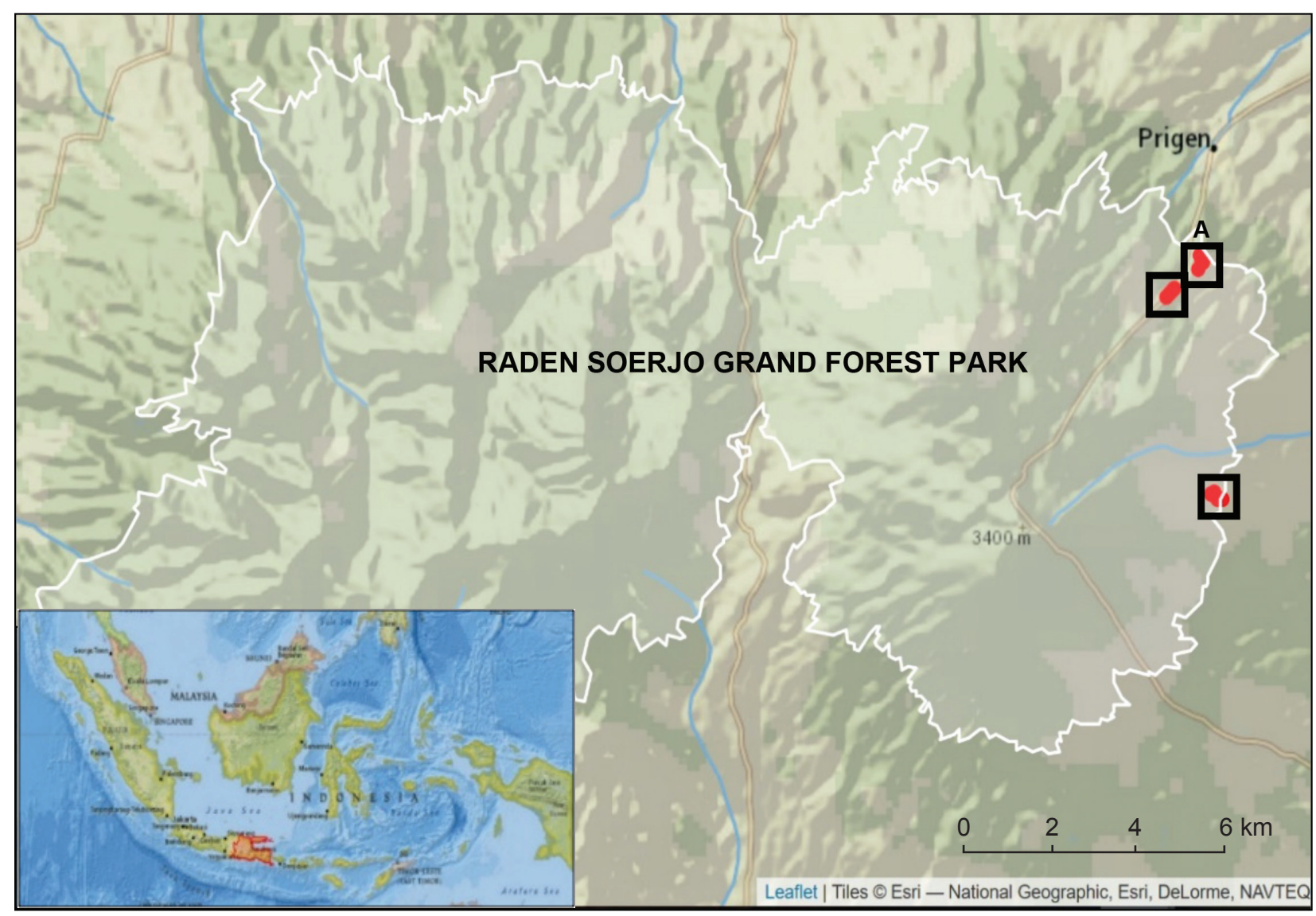

Figure 1 Study site located in the Province of East Java, shown in red on the inset map (right), Raden Soerjo Grand Forest Park (Taman Hutan Raya) and location of three high severity burn units sampled in the study (left); A = TSF8/BI, B = TSF2/BII, C = TSF5/BII 


\section{Field site selection}

The general location sites from Rahmasari (2011) were used to locate areas first burned in 2009 at high severity (Table 1 ). To validate the high-severity burn units reported in Rahmasari (2011), 30-meter spatial resolution, cloud-free Landsat images acquired between 2008-2017, were used. These encompassed six Landsat 7 ETM + and 8 OLI/TIRS collection 1 level 1 images. Acquired images were processed using ENVI 5.4 software, including radiometric calibration, atmospheric correction using Fast Line of Sight Atmospheric Analysis of Spectral Hypercubes (FLAASH) and cloud masking. To assess burn severity, areas that burned in 2009, 2012 and 2015 were examined using normalised burn ratio (NBR) and difference of NBR (dNBR), an index of NBR between preand post-fire spectral signals (Roy et al. 2006). Near-infrared (NIR) and shortwave infrared bands (SWIR) were used to calculate both fire severity indices, using Formula 1 for NBR and Formula 2 for dNBR (United States Geological Survey 2004).

$$
\mathrm{NBR}=\frac{(\mathrm{NIR}-\mathrm{SWIR})}{(\mathrm{NIR}+\mathrm{SWIR})}
$$

$\mathrm{dNBR}$ values $=\mathrm{NBR}$ pre-fire $-\mathrm{NBR}$ post-fire

where NIR was band 4 in Landsat 7 ETM+ and band 5 in Landsat 8 OLI/TIRS, and SWIR was band 7 for both Landsat 7 ETM+ and Landsat 8 OLI/TIRS. The threshold of high-severity fire was defined as values $>0.25$ and as at least $50 \%$ of the investigated units having burned with predicted high ecological damages, including a high level of tree mortality and dark soil $>1$ cm in depth (DeBano et al. 1998, Keeley 2009). Areas within the 2009 high-severity areas that also burned in 2012 or 2015 were identified to assess forest recovery along a fire chronosequence and across areas burned once or twice.

\section{Climate variables during the fires}

To better characterise the weather during the years of fire occurrence, climate data for the period 1999-2017 were obtained from the Indonesia Meteorological, Climatological and Geophysical Agency, including mean temperature, precipitation and relative humidity. Wind velocity and wind direction were also obtained for fire years 2009, 2012 and 2015.

\section{Field data collection}

Thirteen plots were randomly selected and established in July 2017 across three time since fire and two burn entry variables (Table 1). Each plot consisted of a nested circular plot with radius $20 \mathrm{~m}$ ( 0.1 ha, overstory plots) and smaller, sub-plot of radius $5 \mathrm{~m}$ (0.008 ha, sapling plots) established using the same center point. Three square subplots of $1 \mathrm{~m} \times 1 \mathrm{~m}$ (0.0003 ha, understory plots) were established $10 \mathrm{~m}$ from the center point at $0^{\circ}, 120^{\circ}$ and $240^{\circ}$.

All standing (live and dead) trees $\geq 20 \mathrm{~cm}$ diameter at breast height (DBH, $1.4 \mathrm{~m}$ height above ground) and poles (10.0-19.9 cm DBH) in each overstory plot were measured, and DBH and species of each stem were recorded. Saplings $(<10 \mathrm{~cm} \mathrm{DBH}$ and $\geq 1.4 \mathrm{~m}$ tall $)$ were tallied by species in the sapling plots, and seedlings $(<1.4 \mathrm{~m}$ tall) by species in each understory plot. Finally, the coverage (\%) of epiphytes, woody lianas, nonwoody lianas, pandanus, palms and understory in each understory plot were recorded. For understory cover, coverage by nine life form categories were recorded, i.e. herbaceous (HE), woody shrubs (WS), grasses (GR), ferns/fern allies (FE), rock (RO), mosses/lichens (MO), bare ground (BG), wood (WO) and leaves/organic matter $(\mathrm{OM})$. Each life form coverage percentage was recorded to a maximum of $100 \%$ due to extensive ground cover layering in these forests, yielding a possible total percent cover of $900 \%$.

\section{Data analysis}

The analysis summarised burn unit variability of abiotic factors, namely climate, elevation, slope and aspect (Table 1), but did not test for significant differences between categories or burn units, given low sample sizes and influence of topography on burn patterns. All statistical analyses were completed in R 3.4 ( R Core Team 2017).

To address the research objective, data from the burn units were analysed, based on the fire chronosequence (time since fire) and fire frequency (burn entry). In the fire chronosequence, three burn units were investigated including (1) TSF2, a burn unit 
which experienced high-severity fires first in 2009 and second in 2015 (last fire occurrence 2 years ago), (2) TSF5, a burn unit which experienced high-severity fires first in 2009 and second in 2012 (last fire occurrence 5 years ago) and (3) TSF8, a burn unit which experienced high-severity fire only in 2009 (last fire occurrence 8 years ago). To address the effect of burn entry, burn units were categorised as (1) BI, burn units that experienced one high-severity fire in 2009 and (2) BII, burn units that experienced two high-severity fires (Table 1).

Using both, the time since fire and the burn entry variables, post-fire regrowth stand structure were enumerated based on the mean tree density $($ stems ha-1) by size class (trees, poles, saplings, and seedlings), basal area of live trees and poles $\left(\mathrm{m}^{2} \mathrm{ha}^{-1}\right)$, mean percent understory cover by life form category and all life forms combined. Due to low sample size and concerns around statistical test assumptions, observed trends were interpreted using variable means with corresponding standard errors. To define the overstory stand species composition and size class distribution, diameter class distributions were developed for all trees, by species, using four size classes: $10-19.9 \mathrm{~cm}, 20-29.9 \mathrm{~cm}, 30-39.9 \mathrm{~cm}$ and $40+\mathrm{cm}$.

Importance value (IV), Shannon-Wiener diversity index (H'), evenness (E) and species richness or Margalef index (d) were calculated based on the abundance of stems by species recorded in each time since fire unit (Curtis \& McIntosh 1950, Shannon \& Weaver 1963, Pielou 1966, Margalef 1968).

Importance values were computed as the sum of relative density, relative frequency and relative dominance (Smith 1980), and calculated separately for trees, poles, saplings and seedlings. Maximum value of IV can be up to $300 \%$ for tree and pole size classes and $200 \%$ for sapling and seedling size classes (Curtis \& McIntosh 1950, Smith 1980). Dominant species was defined as the most abundant species (highest IV by size class and species) recorded in each time since fire unit (Smith 1980).

The Shannon-Wiener species diversity index $\left(\mathrm{H}^{\prime}\right)$ was calculated to distinguish species variability in times since fire units using Formula 3 (Shannon \& Weaver 1963).

$$
H^{\prime}=-\sum_{i-1}^{s}\left(p_{i}\right)\left(\log _{2} p_{i}\right)
$$

where $s$ is the number of species, $p_{i}$ is the proportion of individuals of the total sample referring to the $\mathrm{i}^{\text {th }}$ species, and $\log _{2}$ is the natural logarithm base 2. The exponents of all total H' values of each species in the site were computed to explore species diversity based on each time since fire unit. An evenness index (E, relative abundance of each species) was calculated according to Pielou (1966) using the following formula:

$$
\mathrm{E}=\frac{\mathrm{H}^{\prime}}{\log \mathrm{S}}
$$

(Formula 4)

where $\mathrm{H}^{\prime}$ is the Shannon-Wienner species diversity index and $S$ is the total number of species. Evenness can be unlimited or undefined if only one species is present.

Finally, the species richness (d) or Margalef index were calculated, as the total number of species recorded in the unit (Margalef 1968) using the following:

$$
\mathrm{d}=\frac{\mathrm{S}-1}{\log \mathrm{N}}
$$

(Formula 5)

where $\mathrm{S}$ is the number of species and $\mathrm{N}$ is total number of all individuals in the burn unit.

\section{RESULTS}

The fire years, 2009, 2012 and 2015 had belowaverage daily precipitation and relative humidity (Figure 2). Additionally, the high-severity fires occurred during the dry season, with precipitation less than $100 \mathrm{~mm} \mathrm{month}^{-1}$ (between June and October), and wet season precipitation during the same years totaled over $400 \mathrm{~mm}$ month $^{-1}$. Wind direction during the the fires was easterly, but no pattern emerged related to wind velocity.

\section{Post-forest fire regrowth, time since fire and burn entry}

Trees ha ${ }^{-1}$ varied between 2.5 and 35 across burn units while total basal area varied between 0.34 and $3.03 \mathrm{~m}^{2} \mathrm{ha}^{-1}$ (Table 2). It was observed that of 17 different tree species, thirteen were native and four were non-native.

Increasing trends were observed in mean tree, sapling and seedling densities with increasing time since fire, from TSF2 (lowest) to TSF8 (highest) (Table 2). First, pole density increased, 
Table 1 High-severity burn units sampled in Raden Soerjo Grand Forest Park, East Java, Java, Indonesia, showing management block location, years burned, time since last fire, burn unit identifiers used in analysis, number of plots installed, and mean plot elevation, slope and aspect

\begin{tabular}{|c|c|c|c|c|c|c|c|c|c|c|}
\hline \multirow{2}{*}{ Location } & \multicolumn{2}{|c|}{$\begin{array}{l}\text { Burning } \\
\text { occurrence }\end{array}$} & \multirow{2}{*}{$\begin{array}{l}\text { Time } \\
\text { since fire } \\
\text { (years) }\end{array}$} & \multicolumn{2}{|c|}{$\begin{array}{l}\text { Burn unit } \\
\text { identifier }\end{array}$} & \multirow{2}{*}{$\begin{array}{c}\# \\
\text { Plots }\end{array}$} & \multirow{2}{*}{$\begin{array}{l}\text { Elevation } \\
\text { (m) }\end{array}$} & \multirow{2}{*}{$\begin{array}{c}\text { Slope } \\
(\%)\end{array}$} & \multirow{2}{*}{\multicolumn{2}{|c|}{$\begin{array}{c}\text { Aspect } \\
\left({ }^{\circ}, \text { direction }\right)\end{array}$}} \\
\hline & $\begin{array}{l}\text { First } \\
\text { entry }\end{array}$ & $\begin{array}{c}\text { Second } \\
\text { entry }\end{array}$ & & $\begin{array}{c}\text { Time } \\
\text { since fire }\end{array}$ & $\begin{array}{c}\text { Times } \\
\text { burned }\end{array}$ & & & & & \\
\hline $\begin{array}{l}\text { Block of Dali } \\
\text { Pentongan } \\
\text { (Village of Ledug } \\
\text { District of Prigen, } \\
\text { Region of Pasuruan) }\end{array}$ & 2009 & - & 8 & TSF8 & BI & 4 & 1148 & 26 & 49 & ENE \\
\hline $\begin{array}{l}\text { Block of Gumandar } \\
\text { (Village of Jatiarjo } \\
\text { District of Prigen } \\
\text { Region of Pasuruan) }\end{array}$ & 2009 & 2012 & 5 & TSF5 & & 5 & 1527 & 14 & 25 & NEE \\
\hline $\begin{array}{l}\text { Block of Sembung } \\
\text { Rubuh } \\
\text { (Village of Pecalukan } \\
\text { Distrcit of Prigen, } \\
\text { Region of Pasuruan) }\end{array}$ & 2009 & 2015 & 2 & TSF2 & DII & 4 & 1465 & 16.5 & 30 & NEE \\
\hline
\end{tabular}

TSF2 = two-years post-fire, TSF5 = five-years post-fire, TSF8 = eight-years post-fire, BI = single burn entry, $\mathrm{BII}=$ two burn entries, $\mathrm{NE}=$ north east, $\mathrm{ENE}=$ east-northeast, $\mathrm{NNE}=$ north-northeast

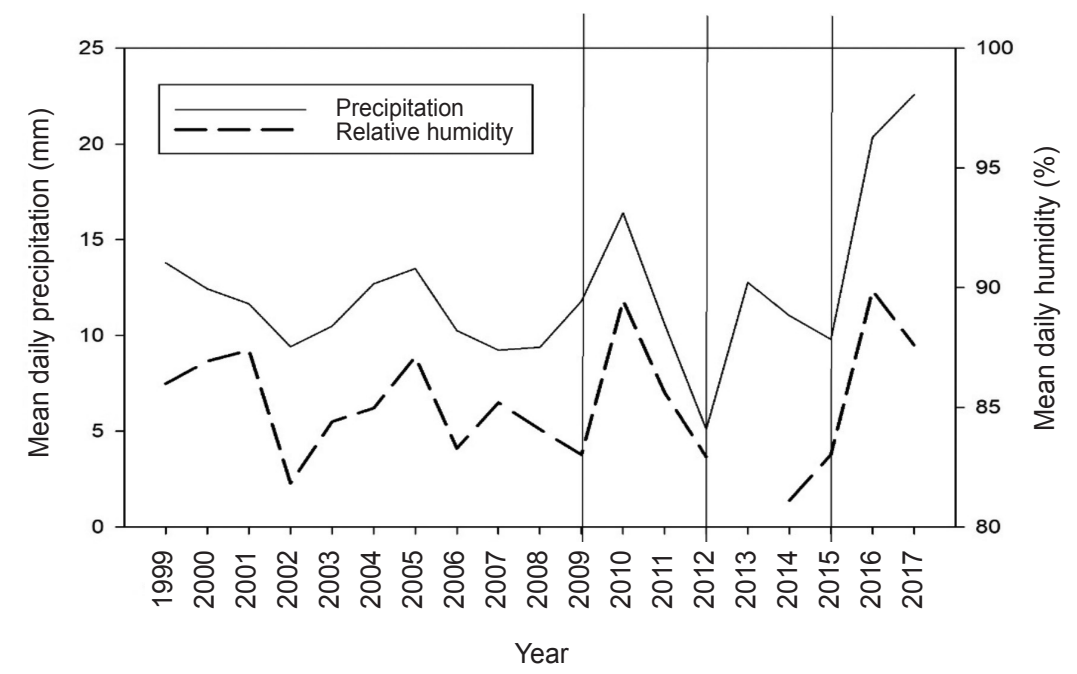

Figure 2 Mean daily precipitation and relative humidity for Raden Soerjo Grand Forest Park, East Java, Java, Indonesia from 1999-2017; note the scale differences between the variables; vertical lines indicate fire years $(2009,2012,2015)$

and then decreased from TSF2 to TSF5, and TSF8 (Table 2). Observations with respect to burn entries varied. Single-entry burns had higher values in all structural variables when compared to second-entry burn units, except for poles where second-entry burn units were highest (Table 2).
Of the four diameter classes, TSF2 and TSF5 were represented by just two, while all four diameter classes were represented in TSF8 (Figure 3a). The diameter class distribution of TSF5 contained two classes, with lower stem densities in the larger size class (Figure 3a). In TSF8, poles and trees were distributed throughout 


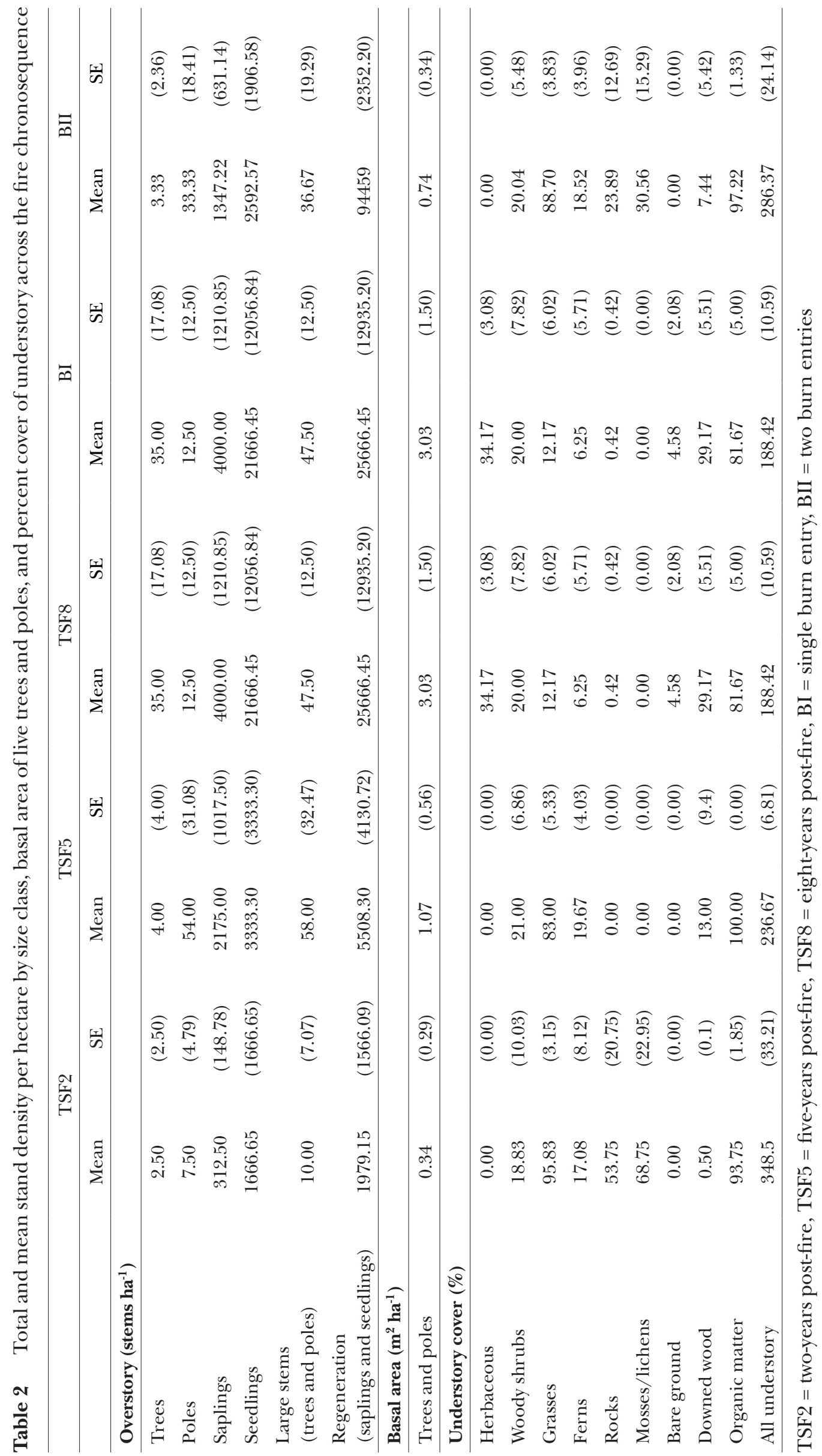


four diameter classes, with a peak in the 20-29.9 $\mathrm{cm}$ class (Figure $3 \mathrm{a}$ ). More diameter classes were represented after a single burn (four) than after a second burn entry (three) (Figure 4a). The single-entry burn contained classes 10-19.9 cm through $40+\mathrm{cm}$, with $20-29.9 \mathrm{~cm}$ having the highest density (Figure 4a). Conversely, a steep reversed-J shaped distribution was found, with three diameter classes in the second-entry burn units (Figure 4a). Total basal area of live trees and poles increased with increasing time since fire (Table 2, Figure 3b) and decreased by $24 \%$ with increasing fire frequency (Figure $4 b$ ).

\section{Species composition}

Four tree species were observed in TSF2, consisting of two native species and two nonnative species (Table 5). Five unique species were found in TSF5 (Table 3), including four native species and one non-native species (Table 3). Acacia decurrens dominated TSF5 among all size classes (Table 5). More species diversity was found in TSF8 (also single-entry burn unit) than in TSF2 or TSF5 (Figures 3a and 5a), primarily composed of native species (10 vs. 2 non-native). The second-entry burned units, BII, contained
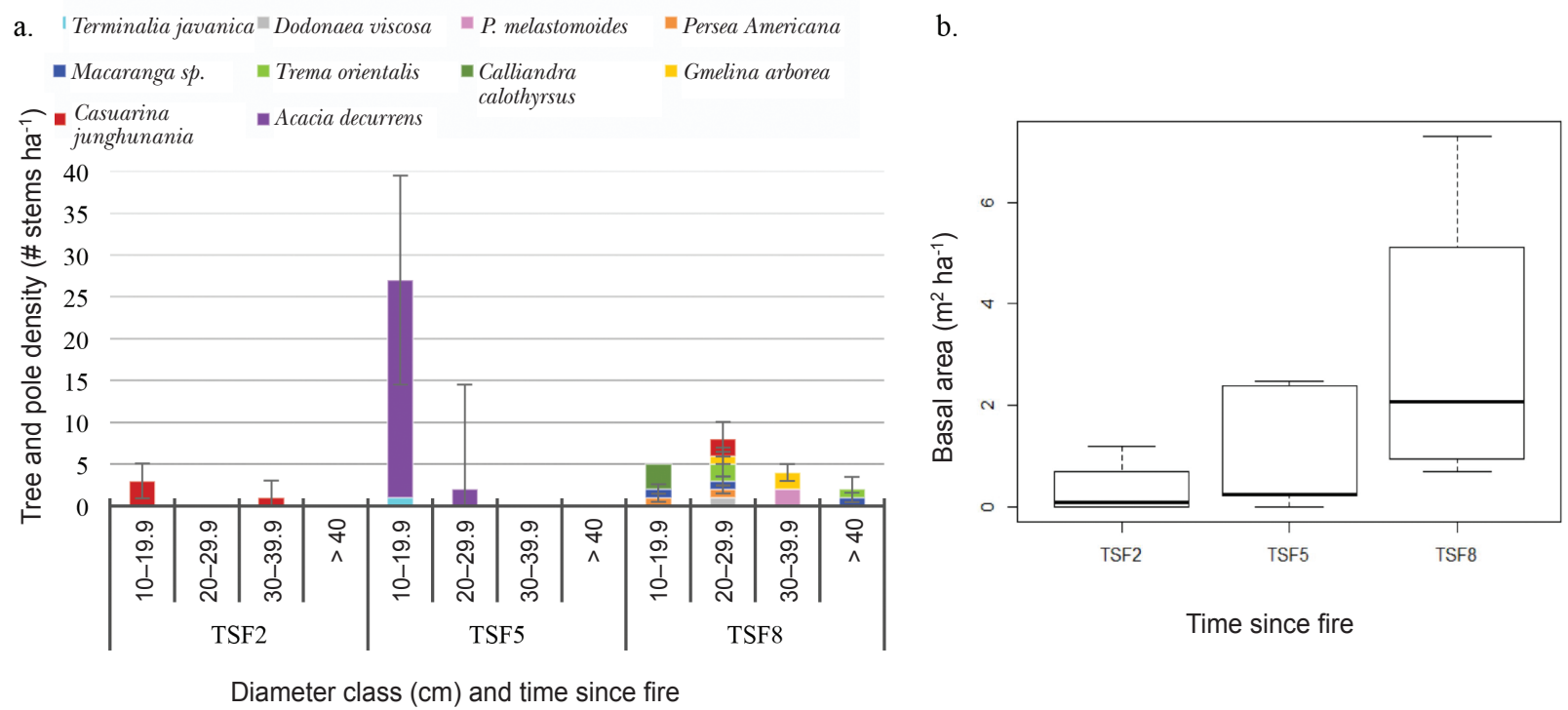

Figure 3 Time since fire (a) diameter class distribution by species and size class and (b) basal area, bars and lines represent category means and standard errors, TSF2 $=$ two-years post-fire, TSF5 $=$ five-years post-fire, TSF8 = eight-years post-fire
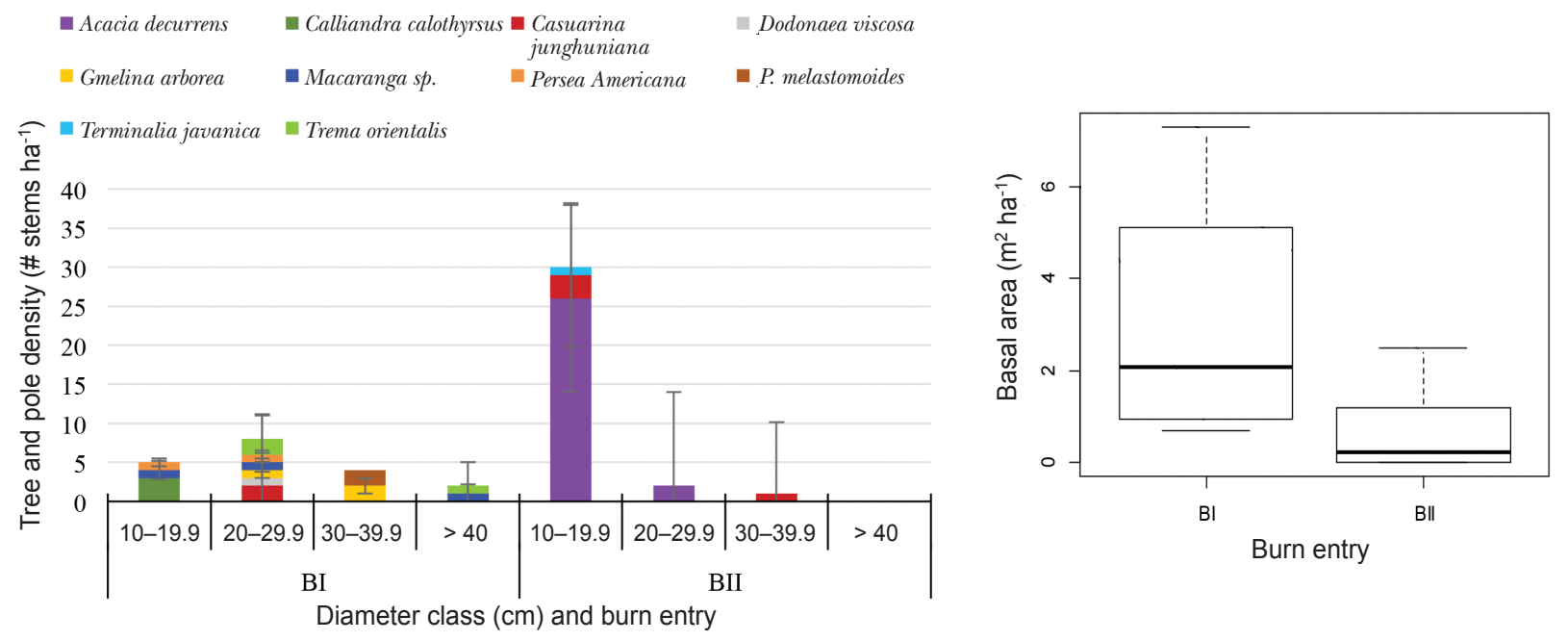

Figure 4 Burn entry (a) diameter class distribution by species and size class and (b) basal area, bars and lines represent category means and standard errors, $\mathrm{BI}=$ single burn entry, BII = two burn entries 


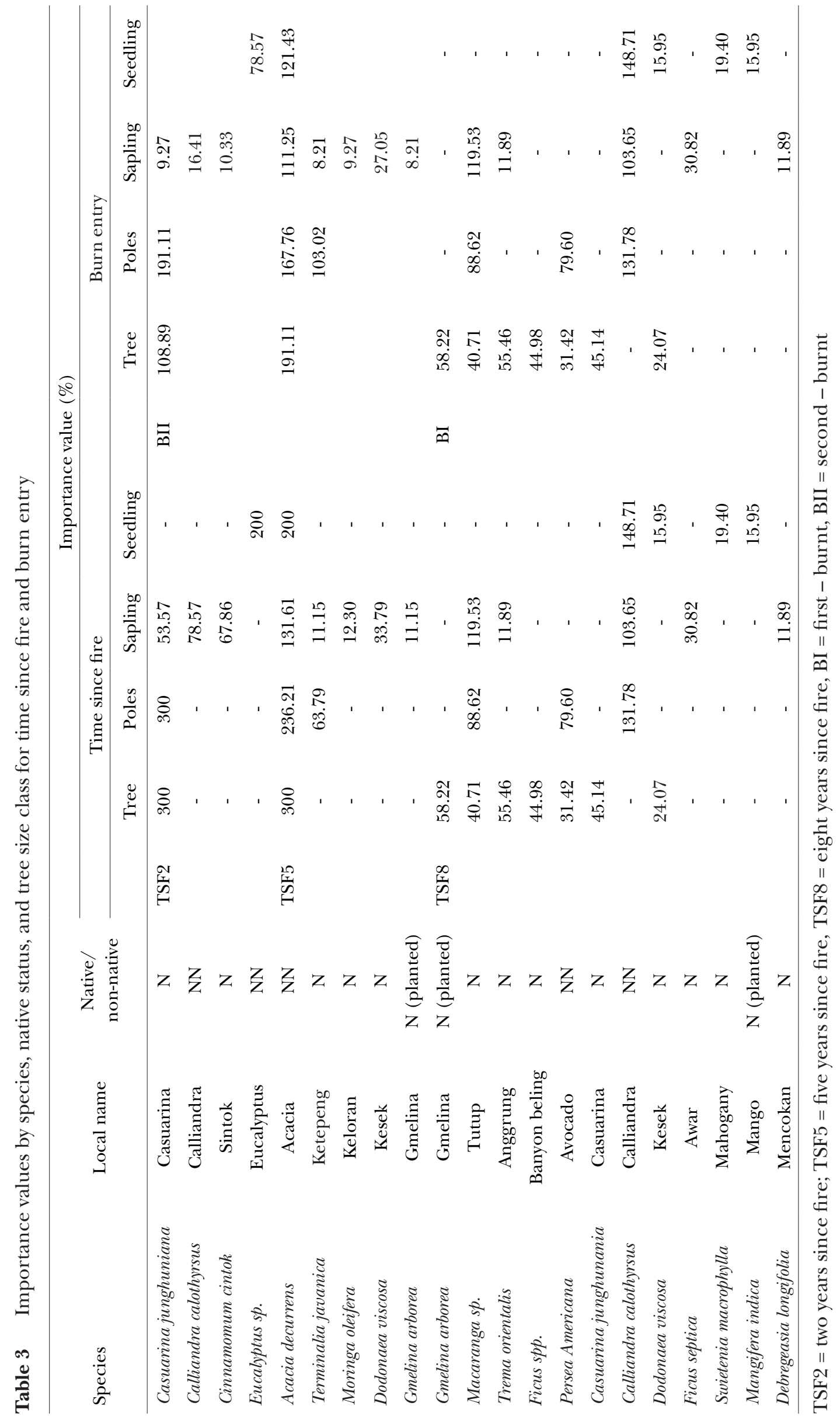


nine species including six native species and three non-native species (Table 3).

Species diversity, species richness and evenness indices differed among time since fire units (Figure 5). An increase in species occurrence was found with additional time since fire, coupled with high variation between burn units (Figure 5 ). Low tree diversity indices were found in TSF2 and TSF5 units, with primarily one species recorded in most size classes (Figure 5). The highest species diversity, richness and evenness indices were assessed in the tree-sized class of TSF8 (Figure 5). Fewer species were found occurring in BII than in BI. No clear trends were observed between $\mathrm{BI}$ and $\mathrm{BII}$ in regeneration size classes in terms of species diversity, richness or evenness (Figure 6). Large stem species diversity, species richness and evenness was higher in $\mathrm{BI}$ than in BII (Figure 6).
In the understory, variable trends were largely observed in cover with time since fire, with many variables exhibiting no cover in several categories (Table 2). The only clear trends observed were a decrease in mean percent cover of grasses and an increase in downed wood with increasing time since fire. Mean percent cover of herbaceous, bare ground and downed wood were found to be higher in single burn entries while grasses, ferns, rocks, mosses and lichens, organic matter and the sum of all understory cover categories were found to decrease with repreated burn entry (Table 2 ).

\section{DISCUSSION}

Relatively, slow forest recovery was found following fire, and native forest recovery was hindered by a second burn and non-native species. Rahmasari (2011) found higher basal

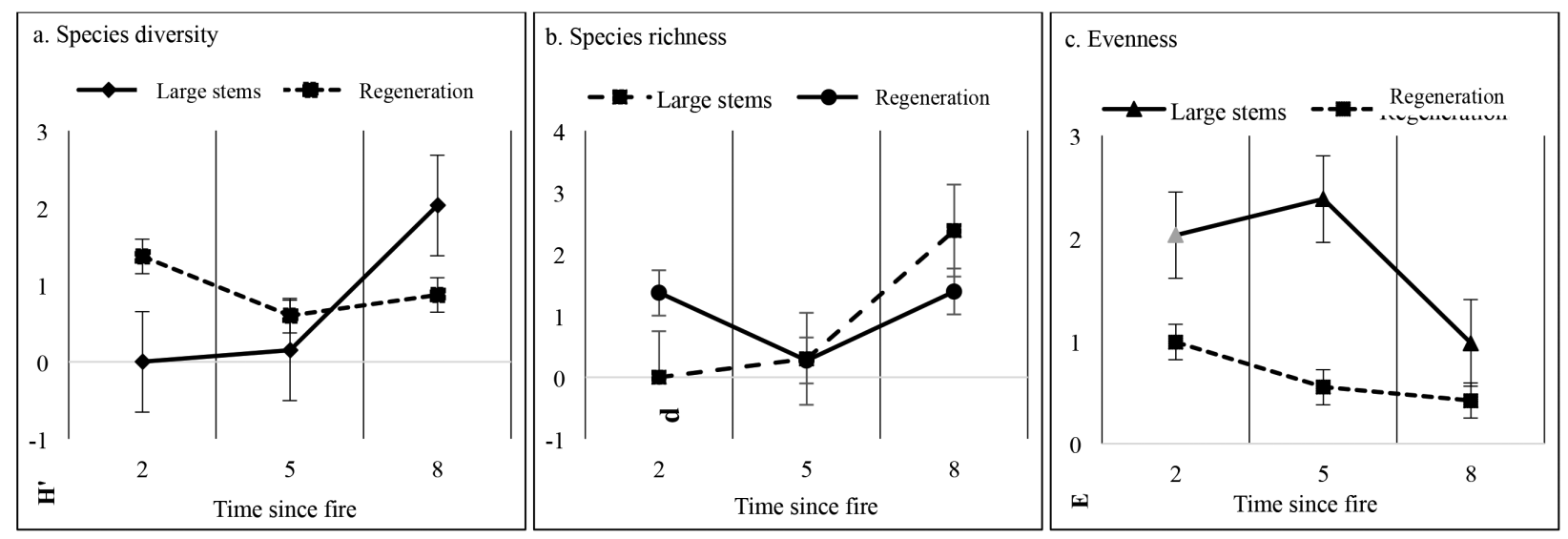

Figure 5 Species diversity (H'), species richness $(d)$, and evenness (E) indices by time since fire and stem size class; points represent means and lines represent $+/$ - one standard error of the mean

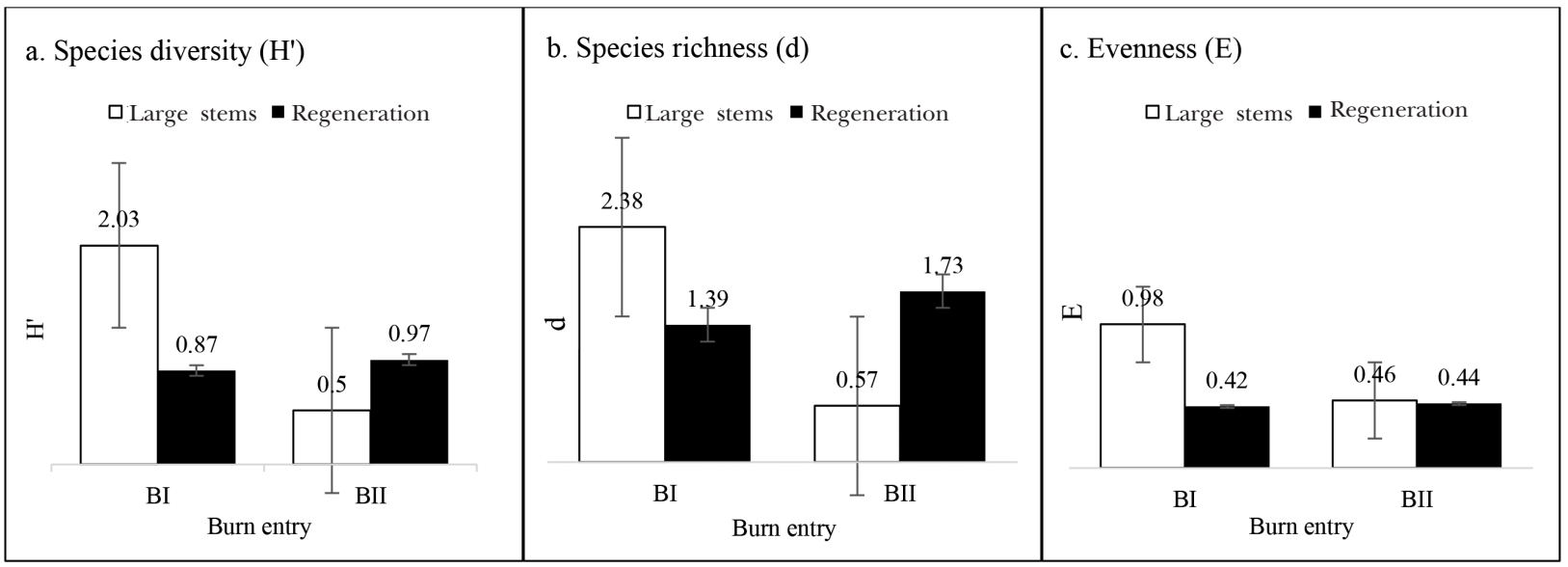

Figure 6 (a) Species diversity (H'), (b) richness (d), and (c) evenness (E) by burn entry and stem size class; bars and lines represent means $+/$ - one standard error, by category 
area, lower stem densities and uneven-sized, reverse-j diameter distribution in similar, unburned forest. Increasing time since fire increased stem density and basal area in the study, as expected. Fire severity may have been enhanced by the dry seasons during which they occurred (Cochrane 2003). Most forest fires in the area are caused by abandoned campfires or intentional burning by poachers looking to flush game species, which peak during the dry season (Raden Soerjo GFP Agency 2015).

Stem density across all size classes increased with prolonged time since fire, and more large stems were present following the single-entry burn, than units with a second-entry. Longer postfire intervals may better promote the recovery of residual and large trees, stressed during the fire, which would also assist with increases in understory tree recruitment and establishment, facilitating initial forest recovery (Donato et al. 2009, Verma et al. 2017). Recruitment and establishment of the understory may be a result of natural regeneration or enrichment planting during post-fire restoration efforts. Lower seedling and sapling densities found in the earlier post-fire years may be a result of competition given the abundant grass coverage (>90\%) (Baudena et al. 2015). Some aggressive native (e.g. Imperata and Sacharum) and nonnative (e.g. Euphotarium and L. camara) grass species were observed in the burn units, however, the observations were limited as understory cover by species was not recorded.

The second-entry burn increased overall mortality but enhanced regeneration, a finding supported by previous research in other systems (Cochrane \& Schulze 1999, Greene et al. 1999). The occurrence of fewer residual trees following the second-entry burn may result in a type of conversion away from forest, if tree recruitment is delayed or unsuccessful given the harsh conditions present on the sites (dry, north-facing slopes), with potential for less seed dispersion by herbivores or mammals, depending on species silvics and gap size, among other factors (Donato et al. 2009, Arroyo-Rodríguez et al. 2017).

In this study, the diameter distribution shifted towards complete dominance by small size classes (seedlings, saplings and poles), while in unburned forest it is expected to find all size classes present, including stems over $100 \mathrm{~cm}$ in diameter, higher overall basal area and less overall density (Rahmasari 2011). Some trees were present in the overstory eight-years postfire, creating a more uneven-sized distribution with comparatively higher total basal areas. These conditions closely resemble second-growth tropical forests of the region than even-sized, small statured structures (Chazdon 2014). The second-entry burn units were dominated by polesized Acacia decurrens, a fire-tolerant species and had overall less basal area than the first-entry burn.

Two years following fire, a CasuarinaCalliandra-Eucalyptus association was found. The native species Casuarina junghuniana is a long-lived, shade-intolerant pioneer tree species of Javan tropical montane that can survive fire (Smiet 1992). However, given that we found no $C$. junghuniana seedlings and declining abundance with increasing stem size classes, competition from other species, namely Eucalyptus sp. and Calliandra calothyrus, may be hindering post-fire recovery (Zouhar et al. 2008). Both of these species are shade-intolerant pioneer trees that can establish quickly following disturbances, such as high-severity fire, and may also be present in unburned forest (National Research Council 1983, Rahmasari 2011, Saharjo \& Gago 2011).

Five-years post-fire and following the secondentry burn, it was observed that the non-native species, Acacia decurrens, dominated many size classes. Native species present in similar or lesser abundances may be suppressed by the domination of Acacia decurrens, an allelopathic tree species that can grow rapidly after a fire or volcanic eruption, creating dense canopies and light limiting conditions in the understory (Padmanaba et al. 2017, Sunardi et al. 2017). Besides its good seed germination, Acacia decurrens can also sprout immediately following fire (Hapsari et al. 2014, Afrianto et al. 2017). These characteristics allow continued growth and reproduction of Acacia decurrens and it is unlikely that other species will successfully establish and dominate. Furthermore, additional burns are likely to continue perpetuating the dominance of Acacia decurrens in these areas, particularly given that most native species do not thrive in the post-fire environment (Sunardi et al. 2017). For example, large stems of $C$. junghuniana may initially survive the fire but have declining seed production after burns (Nieuwstadt 2002).

It was expected to find decreasing species diversity and richness as time since fire increased, and when competition reduced or eliminated 
some species. Observations showed that five years post-fire did not support higher species diversity and richness over those in two-year post-fire, but the eight-year post-fire unit indicated a trend of increasing species diversity and richness, along with decreasing evenness, over the two- and fiveyear post-fire units. In the different burn entries, single-entry burns were expected to support higher diversity and richness than second-entry burns. However, single-entry burns exhibited less diversity and richness of tree regeneration than second-entry burns. Given that the singleentry unit was also eight-years post-fire, these patterns may be driven by a lack of overlapping species in the two- and five-year post-fire units, or the presence of the non-native species, Acacia decurrens, which dominated the five-year post-fire unit.

Burn entry exhibited a clear influence on most understory life form cover values, particularly grass and organic matter. Secondentry burns exhibited increased understory cover, particularly grasses, likely due to their resistance to high-severity fires and their ability to live in highly disturbed areas (Dennis et al. 2001). The grasses, shrubs and herbaceous species reported in this study were generally fire-resistant and shade-intolerant. Such species can inhibit successful establishment and growth of seedlings and saplings (D'Antonio \& Vitousek 1992, Otsamo 2000, Royo \& Carson 2006). Imperata, Euphoratrium and Sacharum were found to be the three most important understory genus, suggesting that their dense cover may inhibit tree regeneration through competition for light and soil resources (Royo \& Carson 2006). Coupled with the low residual large tree density and multiple entry, high-severity burned areas are more susceptible to conversions to non-forest, which may occur as quickly as 10-15 years postfire (D'Antonio \& Vitousek 1992, Chazdon 2003, Oliveras et al. 2014).

The study results and conclusions were restricted to the East Javan dry tropical forests. In addition, there was limited information regarding the cause, influence and origin of individual fires, as well as total fire-affected area and landscapescale severity, all of which are important when examining forest structure and composition. Furthermore, the paucity of the sampling units along with a lack of representative unburned units (i.e., untreated controls) resulted in high variability among units and reduced the ability to make inferences about post-fire response. Lastly, to preform statistical tests, assumptions of homogeneity of variances and normality were necessary to make comparisons using confidence intervals, limiting to inferences about general characteristics of each unit and trends between units. Standard errors were provided to facilitate future work and to document observed variability in sample means.

The findings represented early post-fire forest succession, and further research is needed to determine the impacts of these fires on longterm forests structure and composition (i.e., recovery). At least 10 years is recommended to gain a better understanding of successional development (Donato et al. 2009). In addition, the fire-chronosequence study design may have inherent limitations as each study site may have had differing initial conditions, and thus capture slightly different recovery pathways and different species occurrences and assemblages. However, the chronosequence design still provided useful insights into species occurrence, differentiation and two- and eight-years post-fire effects.

In this study, lower total tree density and basal area were found, compared to the forest inventory reported by the Indonesian Ministry of Forestry, and in comparable to unburned forest (Rahmasari 2011, Kementerian 2014). The Ministry of Forestry suggests a Javan dry secondary forest should have at least 569 trees $\mathrm{ha}^{-1}$ and $15.69 \mathrm{~m}^{2} \mathrm{ha}^{-1}$ of basal area, while the results showed a mean of only 150 trees ha-1 and $11.53 \mathrm{~m}^{2} \mathrm{ha}^{-1}$ (KLHK 2014). In short, the sites were no longer considered forested areas, by this definition, and are in need of restoration/ rehabilitation.

Re-entry of high-severity burns with short return intervals may result in multiple secondary successional trajectories (Nieuwstadt 2002, Donato et al. 2009). Postponed forest maturation may result, if fewer trees were to establish (Chua et al. 2013). This may be the case where abundant and aggressive grass cover outcompetes tree recruitment. Prolonged delay of early stage forest recovery, or the potential disappearance of native tree recruitment, can influence the natural post-fire forest trajectory towards alternative compositions and functional group dominance, such as grass-dominated conditions or monocultures of Acacia decurrens (ArroyoRodríguez et al. 2017). Given the possibility of conversion, frequent burning may create fire- 
prone conditions that are more susceptible to subsequent disturbances (Dennis et al. 2001, Trumbore et al. 2015).

\section{CONCLUSIONS}

The study provided an increased understanding of early, post-fire recovery in tropical montane forests. Fire frequency is expected to increase as climate change and drought interact with humans in these landscapes. Greater understanding is needed if managers are to improve the post-fire forest recovery by implementing appropriate silvicultural techniques, e.g. reforestation (Chazdon 2003).

\section{ACKNOWLWEDGEMENTS}

The research was funded by the United States Agency for International Development-Center for International Forestry Research (USAIDCIFOR) fellowship program. The authors would like to thank the local partners at Raden Soerjo Grand Forest Park, East Java, Indonesia, who made this study possible.

\section{REFERENCES}

Afrianto WF, Hikmat A \& Widyatmoko D. 2017. Growth and habitat preference of Acacia decurrens Willd. (Fabaceae) after the 2010 eruption of Mount Merapi, Indonesia. Asian Journal of Applied Sciences 5: 65-72.

Arroyo-Rodríguez V, Melo FP, Martínez-Ramos M, et al. 2017. Multiple successional pathways in humanmodified tropical landscapes: new insights from forest succession, forest fragmentation and landscape ecology research. Biological Reviews 92: 326-340. https://doi.org/10.1111/brv.12231.

Baudena M, Dekker SC, van Bodegom PM, et AL. 2015. Forests, savannas and grasslands: bridging the knowledge gap between ecology and Dynamic Global Vegetation Models. Biogeosciences 12: 1833-1848. https://doi. org/10.5194/bg-12-1833-2015.

Chazdon RL. 2003. Tropical forest recovery: legacies of human impact and natural disturbances. Perspectives in Plant Ecology, Evolution and Systematics 6: 51-71. https://doi.org/10.1078/1433-8319-00042.

Chazdon RL. 2014. Second Growth: The Promise of Tropical Forest Regeneration in an Age of Deforestation. University of Chicago Press, Chicago.

Chua SC, Ramage BS, Ngo KM, Potts MD \& Lum SK. 2013. Slow recovery of a secondary tropical forest in Southeast Asia. Forest Ecology and Management 308: 153-60. https://doi.org/10.1016/j.foreco.2013.07.053.

Cochrane, M. 2003. Fire science for rainforests. Nature 421: 913-919. https://doi.org/10.1038/nature01437.
Cochrane MA \& Schulze MD. 1999. Fire as a recurrent event in tropical forests of the eastern Amazon: effects on forest structure, biomass, and species composition. Biotropica 31: 2-16. https://doi. $\operatorname{org} / 10.1111 / \mathrm{j} .1744-7429.1999 . t b 00112 . x$.

Curtis JT \& Mcintosh RP. 1950. The interrelations of certain analytic and synthetic phytosociological characters. Ecology 31: 434-455. doi:10.2307/1931497.

D'Antonio CM \& Vitousek PM. 1992. Biological invasions by exotic grasses, the grass/fire cycle, and global change. Annual Review of Ecology and Systematics 23: 63-87. https://doi.org/10.1146/annurev. es.23.110192.000431.

DeBano LF, Neary DG \& Ffolliott PF. 1998. Fire Effects on Ecosystems. John Wiley \& Sons, New York.

Dennis R, Hoffmann A, von Gemmingen G \& Kartawinata K. 2001. Large-scale fire: creator and destroyer of secondary forests in western Indonesia. Journal of Tropical Forest Science 13: 786-799.

Donato DC, Fontaine JB, Robinson WD, Kauffman JB \& LaW BE. 2009. Vegetation response to a short interval between high-severity wildfires in a mixed-evergreen forest. Journal of Ecology 97:142-154. https://doi. org/10.1111/j.1365-2745.2008.01456.x.

Fuller DO, Jessup TC \& SAlim A. 2004. Loss of forest cover in Kalimantan, Indonesia, since the 1997-1998 El Nino. Conservation Biology 18: 249-54. https://doi. org/10.1111/j.1523-1739.2004.00018.x.

Greene DF, Zasada JC, Sirois L, et al. 1999. A review of the regeneration dynamics of North American boreal forest tree species. Canadian Journal of Forest Research 29: 824-839. https://doi.org/10.1139/x98-112.

Hapsari L, Basith A \& Novitasiah HR. 2014. Inventory of invasive plant species along the corridor of Kawah Ijen Nature Tourism Park, Banyuwangi, East Java. Journal of Indonesian Tourism and Development Studies 2: 1-9.

Hoojer A, Page S, Canadell JG, et al. 2010. Current and future $\mathrm{CO}_{2}$ emissions from drained peatlands in Southeast Asia. Biogeosciences 7: 1505-1514.

itTO (International Tropical Timber Organization). 2002. ITTO Guidelines for The Restoration, Management and Rehabilitation of Degraded and Secondary TropicalForests. ITTO Policy Development Series No. 13. ITTO, Yokohama.

Jones GM, Gutiérrez RJ, Tempel DJ, Whitmore SA, Berigan WJ \& Peery MZ. 2016. Megafires: an emerging threat to old-forest species. Frontiers in Ecology and the Environment 14: 300-306. https://doi.org/10.1002/ fee.1298.

KeELey JE. 2009. Fire intensity, fire severity and burn severity: a brief review and suggested usage. International Journal of Wildland Fire 18: 116-26. https://doi. org/10.1071/WF07049.

KLHK (Kementerian Lingkungan Hidup dan Kehutanan). 2014. Potensi Sumber Daya Hutan dari Plot Inventarisasi Hutan Nasional. Direktorat Inventarisasi dan Pemantauan Sumber Daya Hutan, Jakarta.

Margalef R. 1968. Perspectives in Ecological Theory. University of Chicago Press, Chicago.

Margono BA, Potapov PV, Turubanova S, Stolle F \& Hansen MC. 2014. Primary forest cover loss in Indonesia over 2000-2012. Nature Climate Change 4: 730-735. https://doi.org/10.1038/nclimate2277. 
Mostacedo B, Fredericksen TS, Gould K \& Toledo M. 2001. Responses of community structure and composition to wildfire in dry and subhumid tropical forests in Bolivia. Journal of Tropical Forest Science. 13: 488-502.

National Research Council. 1983. Calliandra, a Versatile Small Tree for the Humid Tropics: Report of an Ad Hoc Panel of the Advisory Committee on Technology Innovation, Board on Science and Technology for International Development, Office of International Affairs, National Research Council, in Cooperation with the Perhum Perhutani, Jakarta, Indonesia. Volume 42. National Academy Press, Washington, DC.

Nieuwstadt MGLV. 2002. Trial by fire: postfire development of a tropical dipterocarp forest. PhD thesis. Utrecht University, Utrecht. http://www.library.uu.nl/ digiarchief/dip/diss/2002-0927-111146/inhoud. htm.

Oliveras I, Malhi Y, Salinas N, et al. 2014. Changes in forest structure and composition after fire in tropical montane cloud forests near the Andean treeline. Plant Ecology E Diversity 7: 329-40. https://doi.org $/ 10.1080 / 17550874.2013 .816800$.

Otsamo R. 2000. Secondary forest regeneration under fast-growing forest plantations on degraded Imperata cylindrica grasslands. New Forests 19: 69-93. https:// doi.org/10.1023/A:1006688022020.

Padmanaba M, Tomlinson KW, Hughes AC \& Corlett RT. 2017. Alien plant invasions of protected areas in Java, Indonesia. Scientific Reports 7: 9334. https:// doi.org/10.1038/s41598-017-09768-z.

Pearson TR, Brown S, Murray L \& Sidman G. 2017. Greenhouse gas emissions from tropical forest degradation: an underestimated source. Carbon Balance and Management 12: 3. https://doi. org/10.1186/s13021-017-0072-2.

Pielou EC. 1966. The measurement of diversity in different types of biological collections. Journal of Theoretical Bology 13: 131-144. https://doi.org/10.1016/00225193(66) 90013-0.

R Core Team. 2017. R: A Language and Environment for Statistical Computing. R Foundation for Statistical Computing, Vienna, Austria.

RAHMASARI EK. 2011. Komposisi dan Struktur Pada Areal Hutan Bekas Terbakar (di Areal UPT Taman Hutan Raya R. Soerjo, Malang). Departemen Silvikultur, Fakutas Kehutanan-Institut Pertanian Bogor, Bogor.

Raden Soerjo GFP Agency. 2015. Long-term Master Plan of Raden Soerjo Grand Forest Park Periode 2015-2025 Province of East Java (Rencana Pengelolaan Jangka Panjang Taman Hutan Raya Raden Soerjo Periode 2015-2025 Propinsi Jawa Timur). Unpublished.

Roy DP, Boschetti L \& Trigg SN. 2006. Remote sensing of fire severity: assessing the performance of the normalized burn ratio. IEEE Geoscience and Remote Sensing Letters. 3: 112-116. doi:10.1038/ nature 01437.

Royo AA \& CARSON WP. 2006. On the formation of dense understory layers in forests worldwide: consequences and implications for forest dynamics, biodiversity, and succession. Canadian Journal of Forest Research 36: 1345-1362. https://doi.org/10.1139/x06-025.
SAHARJo BH \& GAGO C. Natural succession after fires at secondary forest in Fatuquero Village, Railaco District, Ermera Regency-Timor Leste. Jurnal Silvikultur Tropika 2: 40-45.

Shannon CE \& Weaver W. 1963. The Mathematical Theory of Communication. University of Illinois Press, Champaign.

Smiet AC. 1992. Forest ecology on Java: human impact and vegetation of montane forest. Journal of Tropical Ecology 8: 129-152. doi:10.1017/ S026646740000626X.

Sмith RL. 1980. Ecology and Field Biology. Harper Collins Publishers, New York.

Sunardi S, Sulistijorini S \& Setyawati T. 2017. Invasion of Acacia decurrens Willd. After Eruption of Mount Merapi, Indonesia. BIOTROPIA-The Southeast Asian Journal of Tropical Biology 24: 35-46. http:/ / dx.doi. org/10.11598/btb.2017.24.1.524.

Sutomo. 2009. Vegetation condition and guidance for forest ecosystem restoration on post fire area of Pohen Hill Batukahu Nature Reserve Bali (a literature review). Jurnal Biologi Universitas Udayana 13: 45-50.

TACCOni L, Moore PF \& Kaimowitz D. 2007. Fires in tropical forests-what is really the problem? Lessons from Indonesia. Mitigation and Adaptation Strategies for Global Change 12: 55-66. https://doi.org/10.1007/ s11027-006-9040-y.

Tepley AJ, Thompson JR, Epstein HE \& Anderson-Teixeira KJ. 2017. Vulnerability to forest loss through altered postfire recovery dynamics in a warming climate in the Klamath Mountains. Global Change Biology. 23: 4117-4132. https://doi.org/10.1111/gcb.13704.

Trumbore S, Brando P \& Hartmann H. 2015. Forest health and global change. Science. 349: 814-818. doi:10.1126/science.aac6759.

Undang-Undang Republik Indonesia. 1990. Nomor 5 Tahun Tentang Konservasi Sumber Daya Alam Dan Ekosistemnya. https://www.pih.kemlu.go.id/files/ UU\%20RI\% 20NO\% 2005\% 20TAHUN\% 201990.pdf

United States Geological Survey. 2004. FIREMON BR Cheat Sheet V4. https://burnseverity.cr.usgs.gov/ pdfs/LAv4_BR_CheatSheet.pdf

Verma S, Singh D, Mani S \& Jayakumar S. 2017. Effect of forest fire on tree diversity and regeneration potential in a tropical dry deciduous forest of Mudumalai Tiger Reserve, Western Ghats, India. Ecological Processes 6: 32. https://doi.org/10.1186/ s13717-017-0098-0.

Wooster MJ, Perry GL \& Zoumas A. 2012. Fire, drought and El Niño relationships on Borneo (Southeast Asia) in the pre-MODIS era (1980-2000). Biogeosciences 9: 317-340. doi:10.5194/bg-9-317-2012.

Zouhar K, Smith JK \& Sutherland S. 2008. Chapter 2: Effects of fire on nonnative invasive plants and invasibility of wildland ecosystems. Pp 7-32 in Zouhar K et al. (eds) Wildland Fire in Ecosystems: Fire and Nonnative Invasive Plants. General Techology Report. RMRS-GTR-42-Volume 6. US Department of Agriculture, Forest Service, Rocky Mountain Research Station, Ogden. 